Review

\title{
Complex Virus-Host Interactions Involved in the Regulation of Classical Swine Fever Virus Replication: A Minireview
}

\author{
$\mathrm{Su} \mathrm{Li}^{\dagger}{ }^{\dagger}$, Jinghan Wang ${ }^{\dagger}$, Qian Yang, Muhammad Naveed Anwar, Shaoxiong Yu and Hua-Ji Qiu * \\ State Key Laboratory of Veterinary Biotechnology, Harbin Veterinary Research Institute, Chinese Academy of \\ Agricultural Sciences, 678 Haping Road, Harbin 150069, China; lisu@hvri.ac.cn (S.L.); \\ wangjinghan1278@163.com (J.W.); yangqian@hvri.ac.cn (Q.Y.); dr.naveed903@gmail.com (M.N.A.); \\ yushaoxiong1987@hotmail.com (S.Y.) \\ * Correspondence: huajiqiu@hvri.ac.cn; Tel.: +86-451-5105-1708 \\ + S.L. and J.W. contributed equally to this article.
}

Academic Editors: Linda Dixon and Simon Graham

Received: 24 April 2017; Accepted: 27 June 2017; Published: 5 July 2017

\begin{abstract}
Classical swine fever (CSF), caused by classical swine fever virus (CSFV), is one of the most devastating epizootic diseases of pigs in many countries. Viruses are small intracellular parasites and thus rely on the cellular factors for replication. Fundamental aspects of CSFV-host interactions have been well described, such as factors contributing to viral attachment, modulation of genomic replication and translation, antagonism of innate immunity, and inhibition of cell apoptosis. However, those host factors that participate in the viral entry, assembly, and release largely remain to be elucidated. In this review, we summarize recent progress in the virus-host interactions involved in the life cycle of CSFV and analyze the potential mechanisms of viral entry, assembly, and release. We conclude with future perspectives and highlight areas that require further understanding.
\end{abstract}

Keywords: classical swine fever virus; virus-cell interactions; attachment; entry; cell apoptosis; virus life cycle

\section{Introduction}

Classical swine fever (CSF), which is caused by classical swine fever virus (CSFV), is a severe and highly contagious disease in pigs that is listed by the World Organization for Animal Health (OIE). The disease is distributed in many countries and areas including Asia, Eastern Europe, Russia, and South America [1]. Currently, CSF is prevented by stamping-out (non-vaccination) and systemic prophylactic (vaccination) policies [2]. In China, vaccines based on C-strain, a lapinized live attenuated vaccine strain, have been widely used to control CSFV infections in the pig population. Therefore, large-scale outbreaks have been rarely observed in the field during the past decades. However, annual sporadic epizootics or endemics in some regions are continuously being observed. A mild, atypical form of the disease with a long duration, atypical clinical signs, and relatively low morbidity and mortality has been observed constantly, even in a proportion of vaccinated pigs [3]. Based on the phylogenetic analysis of nucleotide sequences, there are three genotypes of CSFV isolates, which can be further divided into 11 subgenotypes. So far, there is no clear correlation between specific sequence motifs and the virulence of the different field strains [4,5].

CSFV is an enveloped, positive-sense, single-stranded RNA virus, which belongs to the Pestivirus genus of the Flaviviridae family [6]. The genome of CSFV contains a $5^{\prime}$-noncoding region (5'-NCR), a large open reading frame (ORF), and a $3^{\prime}-\mathrm{NCR}$. The ORF is translated into a precursor polyprotein of 3898 amino acids (aa), which is cleaved into four structural proteins (C, $E^{\text {rns }}, E 1$, and E2) and eight 
non-structural proteins (Npro, p7, NS2, NS3, NS4A, NS4B, NS5A, and NS5B) (Figure 1) [7]. CSFV enters the host through the mucous membranes of the oral and nasal cavities, and initially infects cells of the tonsil, then spreads around the body via the blood and lymph circulation. CSFV has a distinct tropism for cells of the immune system, which causes severe leukopenia that is associated with apoptosis of leukocytes in the thymus, spleen, lymph nodes, and bone marrow of infected pigs [8,9]. The eventual outcomes of virus infection are generally associated with complex and multifaceted host responses to the virus.

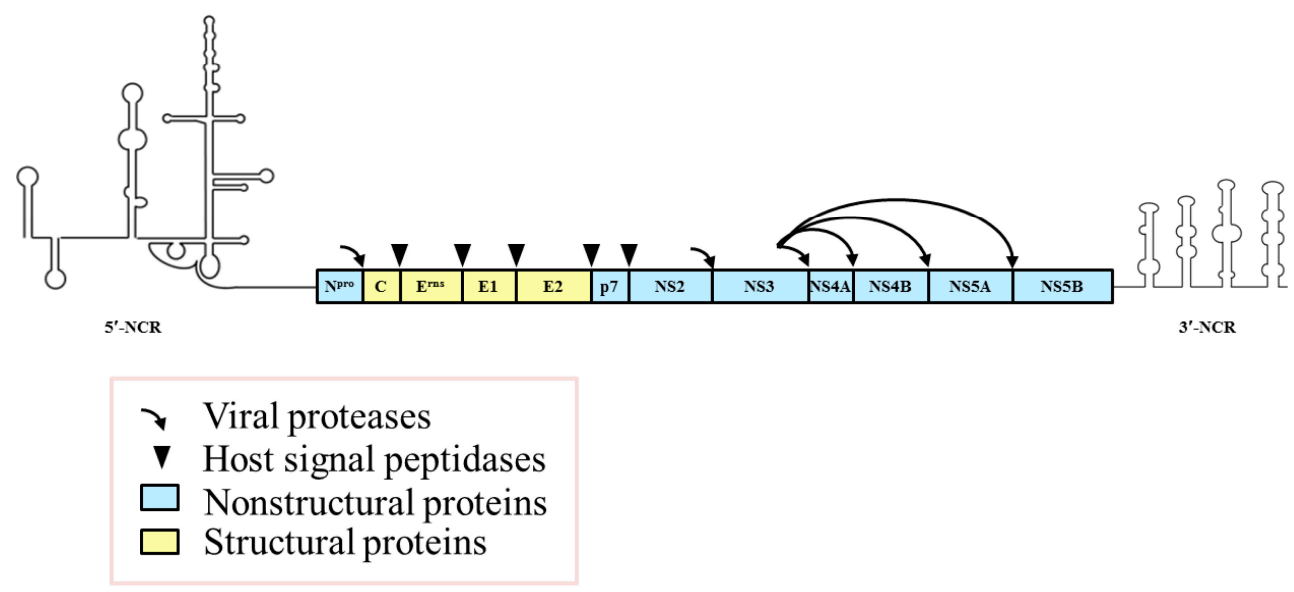

Figure 1. The organization of the classical swine fever virus (CSFV) genome and the encoding proteins. The positive-sense, single-stranded RNA genome of $12.3 \mathrm{~kb}$ contains $5^{\prime}$ - and $3^{\prime}$-noncoding regions (NCRs) important for viral RNA replication and/or protein translation and a large open reading frame (ORF) that encodes a large polyprotein. The polyprotein is processed into four structural proteins and eight nonstructural proteins by a combination of viral and cellular proteases.

This review aims to summarize recent progress in the virus biology and virus-host interactions at the interface of virus replication, and highlight potential mechanisms in the CSFV life cycle. The review concludes with future perspectives and highlights areas that require further understanding.

\section{The CSFV Envelope Proteins Mediate Virus Attachment and Entry}

The structural components of the CSFV virions include a capsid protein $(C)$ and three envelope glycoproteins ( $E^{\text {rns }}, E 1$, and E2). The glycoproteins are processed from the precursor $E^{\text {rns }}-E 1-E 2$ by the host signal peptidase. The $\mathrm{E}^{\mathrm{rns}}$ protein consists of 227 aa with a molecular weight of around $48 \mathrm{kDa}$, which is glycosylated with carbohydrate moieties at seven glycosylation sites [10]. Due to the unusual $\mathrm{C}$ terminus, the protein is loosely associated with mature virions and is also secreted into the medium of cultured infected cells. In general, $\mathrm{E}^{\mathrm{rns}}$ is present as a homodimer (with a molecular mass of about $100 \mathrm{kDa}$ ) [11] and a heterodimer with E2 [12] on the virion. The ectodomain of $\mathrm{E}^{\text {rns }}$ contains five $\alpha$ helices and seven $\beta$ strands with a concave and a convex face and is stabilized by four intramolecular disulfide bonds [13]. In addition, structural analyses of the C-terminus of $E^{\text {rns }}$ show that the amphipathic $\alpha$-helix is inserted slightly tilted into the membrane [14]. $E^{\text {rns }}$ possesses ribonuclease activity, induces lymphocytes apoptosis, and antagonizes the response of type I interferon (IFN) signaling. In addition, the interaction between $\mathrm{E}^{\text {rns }}$ and membrane-associated heparan sulfate (HS) [15] or laminin receptor (LamR) [16] mediates virus attachment. CSFV cultured in swine kidney cells (SK6 cells) selects a virus variant (with S476R mutation) of $\mathrm{E}^{\mathrm{rns}}$ that attaches to the surface of cells by interacting with HS [15].

The E1 glycoprotein consists of 195 aa with an apparent molecular mass of $33 \mathrm{kDa}$, which contains three $N$-linked putative glycosylation sites and six cysteine residues. E1 is a type I transmembrane protein with an $\mathrm{N}$-terminal ectodomain and a C-terminal hydrophobic anchor that attaches E1 to the envelope of the virus [11]. E1 and E2 form heterodimers via disulfide bridges between cysteine 
residues that are present in the CSFV virions. The formed heterodimers then mediate the process of viral entry $[17,18]$.

The E2 protein is a 55-kDa glycoprotein that consists of 373 aa, and contains six N-linked and one O-linked putative glycosylation sites. E2 possesses an $\mathrm{N}$-terminal signal peptide and a C-terminal transmembrane domain that anchors E2 to the viral envelope. The CSFV E2 protein forms disulfide-linked homodimers with molecular weights of $100 \mathrm{kDa}$. E2 is the most immunogenic of the CSFV glycoproteins, in terms of inducing neutralizing antibodies and protection against lethal virus challenge [19-22]. Removal of the glycosylation sites of E2 can significantly reduce the immunogenicity of the protein [23]. Antigenic mapping of $\mathrm{E} 2$ has been determined that attributes to domains A to D using a panel of monoclonal antibodies (MAbs) [24]. The antigenic epitopes of domains D/A, but not the domains $\mathrm{B} / \mathrm{C}$, are the most conserved epitopes. A highly conserved neutralizing linear epitope in the domain A, 829TAVSPTTLR837, which is recognized by the MAb WH303, has been identified [25]. The epitope is widely used to develop marker vaccines [26-28] and diagnostic assays [27,29]. However, the crystal structure of the CSFV E2 protein has not been resolved so far, which renders it difficult to map conformational epitopes on the protein. The CSFV E2 protein shares a sequence identity of $65 \%$ with the bovine virus diarrhea virus (BVDV) E2 protein. Recently, the crystal structure of the BVDV E2 has been resolved, which can be divided into three domains (I to III) [30]. Comparative analysis of the E2 proteins revealed that domains I and II of BVDV correspond to CSFV antigenic domains $\mathrm{B} / \mathrm{C}$ and $\mathrm{D} / \mathrm{A}$, respectively. E2 is characterized as a class II fusion protein that harbors two fusion peptides, ${ }^{818} \mathrm{CPIGWTGVIEC}{ }^{828}$ and ${ }^{869} \mathrm{CKWGGNWTCV}^{878}$ (Figure 2). Interestingly, the peptides exert membrane fusion activity and play critical roles in viral replication and virulence [31,32]. The mechanism of the fusion process of pestiviruses has not been fully elucidated. Based on the crystal structure of the BVDV E2 protein, $\mathrm{Li}$ and his colleagues presumed three potential fusion mechanisms for pestiviruses: (a) the aromatic residues in domain IIIc of E2 function as a fusion motif, (b) domain I of E2 contains a fusion motif, and (c) E1 contains the fusion motif and E2 functions as a coeffector [30]. Another study has also resolved the structure of the BVDV E2 protein and presumed that $\mathrm{E} 2$ becomes disordered at low $\mathrm{pH}$ and exposes the fusion loop of E1, thus mediating the fusion between viral envelope and endosome membrane [18]. In addition, several host cellular factors have been shown to be associated with E2 and are involved in the CSFV life cycle, e.g., CD46 has been identified as a receptor for BVDV using an anti-E2 idiotypic antibody [33], which also functions as an important factor for the attachment of CSFV [34]. Host factors that mediate viral attachment have been defined, but the functional receptor(s) of CSFV has not been determined, and the process of fusion should be focused on future studies.

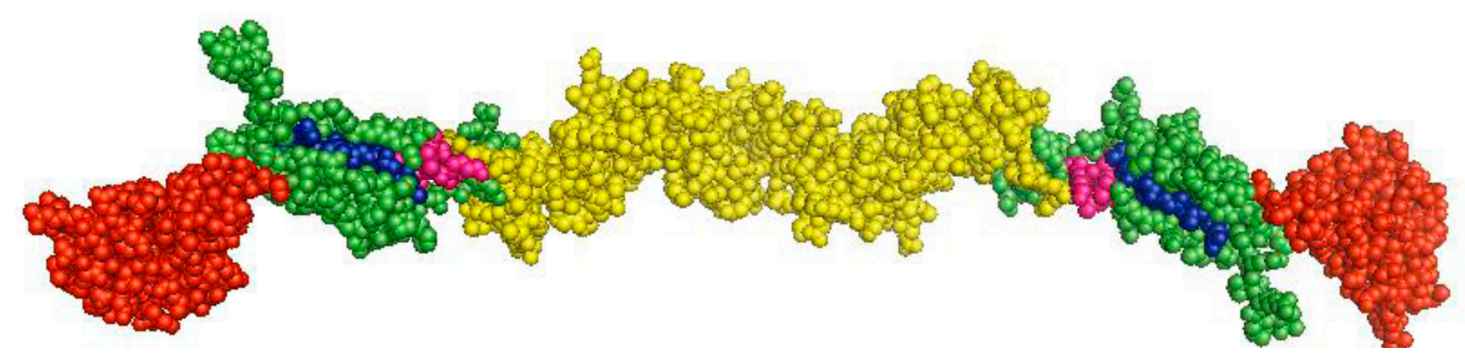

Figure 2. Predicted three-dimensional structure of the CSFV E2 protein. Homology modeling analysis of the CSFV E2 protein was performed using the software PyMOL 1.7 according to the structure of the BVDV E2 protein. Domains B/C are shown in red, domains D/A in green, the other region in yellow, and the fusion peptides (FP1 and FP2) of E2 in blue or purple.

\section{Modulation of Viral Genomic Replication and Translation by NCRs and Nonstructural Proteins (NSPs)}

The $5^{\prime}$ - and $3^{\prime}$-NCRs of CSFV, approximately 373 and 228 nucleotides (nt) in length, respectively, form stem-loops at the $\mathrm{N}$ - and C-termini of the genome [7]. The $5^{\prime}$-NCR does not contain the cap 
structure, but harbors an internal ribosome entry site (IRES) to initiate cap-independent translation. The $3^{\prime}$-NCR, lacks a poly(A) tail but contains a variable AU-rich region and a conserved region, is involved in the initiation of viral genome replication [35]. The NSPs of CSFV consist of Npro, NS2, NS3, NS4A, NS4B, NS5A, and NS5B. Npro , NS2, NS3, and NS4A have been shown to be involved in the cleavage of the NSPs. A previous study has shown that NS3, NS4A, NS4B, NS5A, and NS5B are required for CSFV replication [36]. NS2, a transmembrane protein, harbors an auto-protease activity that is responsible for cis-cleavage of NS2-3 [37]. Previous studies have shown that the uncleaved NS2-3 is crucial for the generation of infectious viral particles for CSFV or BVDV [38,39]. However, additional evidence suggests that the uncleaved NS2-3 is not required for the virion morphogenesis of pestiviruses [40]. As a multifunctional protein, NS3 acts as serine protease, helicase, and nucleoside triphosphatase (NTPase) [41-43]. NS3 and its cofactor, NS4A, process all downstream cleavage sites of viral NSPs [44]. The structure of the NS3-NS4A complex reveals surface interactions between the NS3 protease domain and NS4A-kink region that is required for RNA replication and replicase assembly [45]. NS4B contains two conserved domains, Walkers A (aa 209-216) and B (aa 335-342). Walker A exhibits NTPase activity and is essential for RNA replication [46]. Analysis of simple modular architecture research tool (SMART) has revealed that NS4B contains a Toll/interleukin-1 receptor (TIR)-like domain, and mutations in the TIR-like domain of NS4B significantly attenuate the virulence of CSFV in pigs [47]. The CSFV NS5A contains the conserved sequence $C^{2717}-C^{2740}-C^{2742}-C^{2767}$, which forms the zinc-binding motif that is required for viral RNA synthesis and viral growth. The NS5A protein of BVDV or hepatitis C virus (HCV) is a highly-phosphorylated protein [48]. Similarly, several potential phosphorylated sites of the CSFV NS5A can also be found using the bioinformatic analysis (NetPhos 3.1 Server). It has been reported that NS5A can induce the autophagy pathway of host cells and enhance viral replication [49]. A recent study shows that the inhibition of autophagy promotes apoptosis in CSFV-infected cells via the reactive oxygen species (ROS)-dependent retinoic acid inducible gene I (RIG-I)-like receptor signaling pathway [50]. NS5B is an RNA-dependent RNA polymerase (RdRp) that harbors a conserved motif GDD, which is in charge of RNA replication [51]. The structure of pestiviral NS5B proteins resembles a right hand with fingers, palm, and thumb domains, thus exhibiting the typical general fold of RdRp [52]. It has been shown that NS3, NS4A, NS4B, NS5A, and NS5B are sufficient for the genome replication [36]. The interactions between NSPs and NCRs have been determined to be involved in modulation of RNA replication and translation [53-55].

The CSFV genome can be transcribed into negative-strand RNA that can be used as the template to produce the positive-strand RNA. During this process, NS5B binds to the negative-strand RNA to produce more positive-strand RNA copies [44]. Moreover, NS3 interacts with NS5B and enhances the NS5B RdRp activity through its N-terminal protease domain. NS5A regulates viral RNA synthesis through interacting with NS5B and 3'-NCR [56]. When NS5A is present at a lower expression level in the cells, it preferably interacts with NS5B and enhances viral RNA replication. But oversaturated NS5A will interact with $3^{\prime}-\mathrm{NCR}$ and thus inhibit viral RNA replication [56]. It is likely that CSFV modulates RNA replication via the regulation of NS5A expression.

Unlike cellular mRNA, the CSFV genome lacks $5^{\prime}$-terminal cap structure, and the IRES located in the $5^{\prime}$-NCR can be recognized by the ribosome to initiate translation [57]. NS3 can bind to IRES and promote IRES-mediated translation [54]. In comparison with NS3, NS5A inhibits the IRES-mediated translation, whereas NS5B can suppress the effect of NS5A on the IRES [55]. In addition, NS5B can stimulate NS3 to increase the efficiency of viral genome translation [54].

\section{Interactions between CSFV and Host Cellular Proteins Are Necessary for the CSFV Life Cycle}

During CSFV infection, interactions between the virus and HS/LamR mediate virus attachment [15,16]. Subsequently, virus entry is a dynamin-, and cholesterol-dependent, and clathrin-mediated endocytosis that requires Ras-related in brain ( $\mathrm{Rab}) 5$ and Rab7 [58]. The fusion between cellular membrane and viral envelope is $\mathrm{pH}$-dependent and is triggered by the acidification of the endosome. Another pestivirus, BVDV entry also requires clathrin-mediated endocytosis and low endosomal $\mathrm{pH}$ [59]. 
Similarly, Rab5 and Rab7 are involved in the life cycles of HCV [60], dengue virus (DENV) [61], and West Nile virus [62] that belong to the family Flaviviridae. It has been demonstrated that the peptides ${ }^{129}$ CPIGWTGVIEC ${ }^{139}$ and ${ }^{180}{ }^{18 K W G G N W T C V}{ }^{189}$ of the CSFV E2 protein mediate fusion between viral envelope and cellular membrane [31,32] (Figure 2). After uncoating, the viral genome is released and translated into the viral proteins, followed by the cleavage of the cellular and viral proteases. In addition, the viral genome can be transcribed into negative-strand RNA, which is used as a template to produce progeny positive-sense RNA. Virion morphogenesis is mediated by NS2-3 and NS4A [38]. Then, the virion is released from the host cells (Figure 3). Host cellular factors also participate in various steps of the life cycle of CSFV.

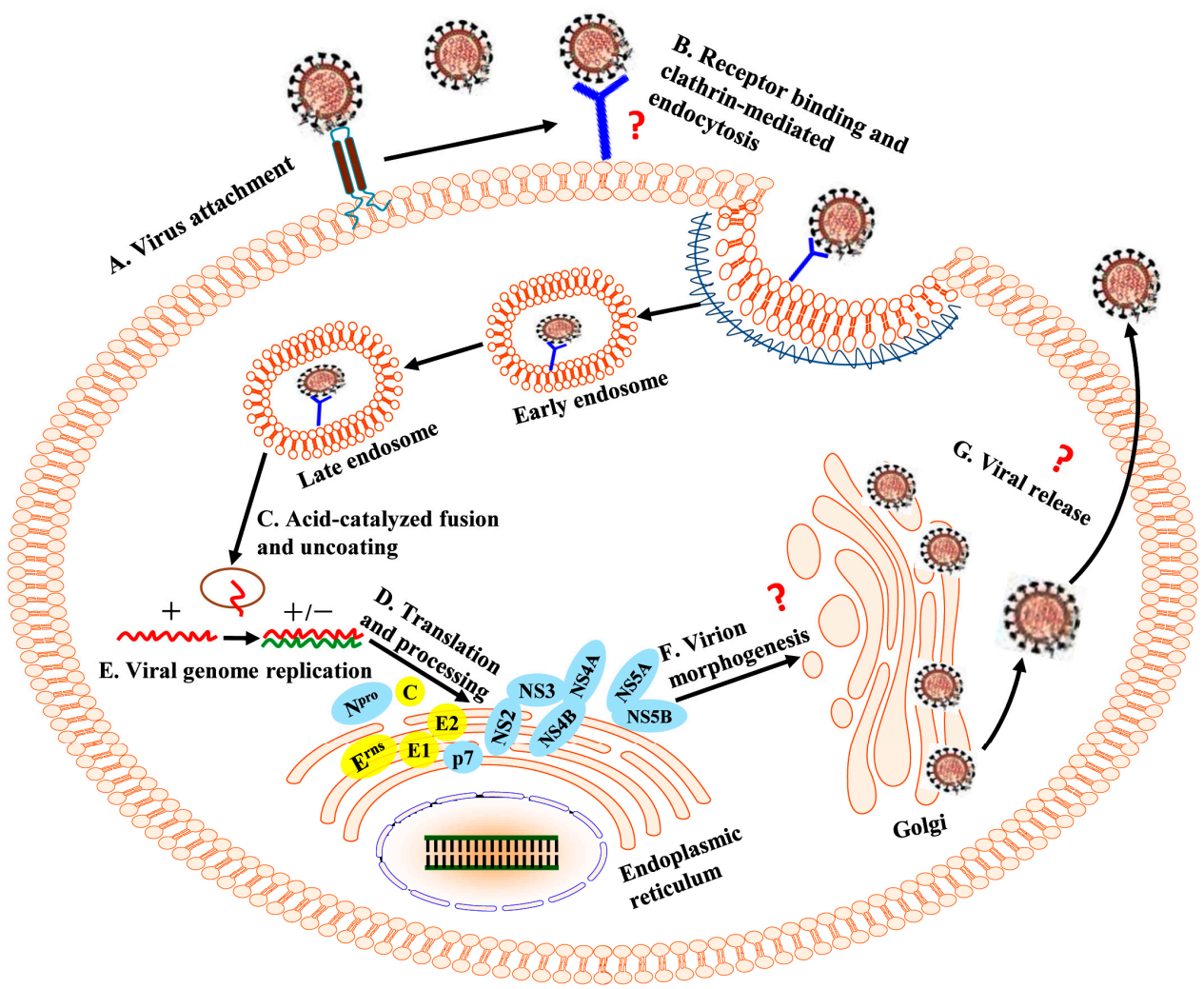

Figure 3. Schematic diagram of the CSFV life cycle. (A) Interactions between $E^{\text {rns }}$ and host cellular heparan sulfate (HS) and/or laminin receptor (LamR) mediate virus attachment. (B) Virus binds to an unknown entry receptor(s) and triggers clathrin-mediated endocytosis. (C) Low $\mathrm{pH}$ facilitates viral envelope and membrane fusion. (D) Translation and processing of viral proteins. (E) Viral genome replication. (F) Virion morphogenesis harbors an unknown strategy. (G) Mature virions are released from the cell via an unknown secretory pathway. +, positive-strand genomic RNA; +/-, positive- and negative-strand replicative intermediate.

\subsection{Host Factors Modulate the Production of Progeny Virus}

The interactions between flaviviruses and cytoskeleton are involved in the entry, transport, assembly, and egress processes [63]. The cellular $\beta$-actin interacts with the E2 protein and affects the early stage of the replication cycle of CSFV [64], which is most likely related to the interaction affects intracellular transport process of CSFV or E2 protein in the cell at the post-entry step. Annexin A2 $($ Anx2) is a lipid raft-associated scaffold protein that functions in membrane trafficking, aggregation of vesicles, and endosome formation. Anx2 is involved in the regulation of the life cycles of many viruses, such as cytomegalovirus [65], human immunodeficiency virus type 1 [66], influenza virus [67], and HCV [68]. Anx2 interacts with E2 and promotes CSFV production [69], and treatment of PK-15 cells with Anx2-specific polyclonal antibody significantly inhibited CSFV growth, thus we presume 
that Anx2 likely participates in the virus attachment or entry. In addition, interaction between Anx2 and NS5A enhances the virus assembly rather than in genome replication and virion release [70]. It is possible that Anx2 participates in the multiple steps of the CSFV life cycles. The interaction between $\mathrm{C}$ and osteosarcoma amplified protein 9 (OS9) inhibits the virus replication in the cell culture [71]. Host factors also affect NS5A-regualted viral genome synthesis and translation, e.g., heat shock protein 70 (HSP70) interacts with NS5A and promotes viral RNA replication [72]. Furthermore, eukaryotic elongation factor 1A (eEF1A) has been shown to interact with NS5A of CSFV and inhibit IRES-mediated translation efficiency [73] (Table 1). eEF1A also binds to the NS5A protein of BVDV. However, the effect of eEF1A on the BVDV replication remains unclear [74]. It is plausible to speculate that eEF1A is a broad host factor that interacts with the pestiviral NS5A protein.

Table 1. Interactions between classical swine fever virus (CSFV) and host cellular proteins and replication cycle-contributing factors.

\begin{tabular}{|c|c|c|c|}
\hline Viral Proteins & $\begin{array}{l}\text { Interacting Partners or } \\
\text { Replication } \\
\text { Cycle-Contributing Factors }\end{array}$ & Functions & Ref. \\
\hline $5^{\prime}-$ and $3^{\prime}-\mathrm{NCRs}$ & RHA & $\begin{array}{c}\text { Modulation of RNA synthesis, replication and } \\
\text { translation of CSFV }\end{array}$ & [75] \\
\hline \multirow{5}{*}{$N^{\text {pro }}$} & IRF-3 & Blockage of IFN- $\beta$ production & [76] \\
\hline & IRF-7 & Blockage of IFN- $\alpha$ production & [77] \\
\hline & PCBP1 & Blockage of IFN- $\beta$ production & [78] \\
\hline & $\mathrm{I} \kappa \mathrm{B} \alpha$ & - & [79] \\
\hline & HAX-1 & Cellular resistance to apoptosis & [80] \\
\hline \multirow{5}{*}{$\mathrm{C}$} & OS9 & Regulation of virus replication & {$[71]$} \\
\hline & $\mathrm{HB}$ & Blockage of IFN- $\beta$ production & [81] \\
\hline & UBC9 & Involvement of viral virulence & [82] \\
\hline & SUMO-1 & Involvement of viral virulence & [82] \\
\hline & IQGAP1 & Involvement of viral virulence & [83] \\
\hline \multirow{2}{*}{$\mathrm{E}^{\mathrm{rns}}$} & HS & Attachment receptor & [15] \\
\hline & LamR & Attachment receptor & [16] \\
\hline \multirow{4}{*}{ E2 } & $\beta$-Actin & Regulation of virus replication & [64] \\
\hline & Anx2 & Regulation of virus growth & [69] \\
\hline & $\operatorname{Tr} \times 2$ & Inhibition of the NF- $\mathrm{KB}$ signaling & [84] \\
\hline & MEK2 & Inhibition of the JAK-STAT signaling & [85] \\
\hline \multirow{4}{*}{ NS5A } & Anx2 & Regulation of viral assembly & [70] \\
\hline & HSP70 & Regulation of virus replication & [72] \\
\hline & eEF1A & Inhibition of IRES-mediated translation efficiency & [73] \\
\hline & GBP1 & Regulation of virus replication & [86] \\
\hline- & CD46 & Involvement of virus attachment & [34] \\
\hline- & Clathrin & Involvement of virus internalization & {$[58]$} \\
\hline- & Cholesterol & Involvement of virus internalization & {$[58]$} \\
\hline- & Dynamin & Involvement of virus internalization & {$[58]$} \\
\hline- & Rab5 & Involvement of virus internalization & {$[58]$} \\
\hline- & Rab7 & Involvement of virus internalization & {$[58]$} \\
\hline- & $\mathrm{HO}-1$ & Regulation of virus replication & [87] \\
\hline
\end{tabular}

NCR: noncoding region; RHA: RNA helicase A; IRF: interferon regulatory factor; IkB $\alpha$ : inhibitor of kappa B; HAX-1: HS-1-associated protein X 1; PCBP1: Poly(C)-binding protein 1; IFN: interferon; SUMO-1: small ubiquitin-like modifier 1; UBC9: SUMO-1-conjugating enzyme 9; IQGAP1: Ras GTPase-activating-like protein 1; HB: hemoglobin subunit beta; OS9: osteosarcoma amplified protein 9; HS: heparan sulfate; LamR: laminin receptor; Trx2: thioredoxin 2; NF- $\mathrm{kB}$ : nuclear factor kappa-light-chain-enhancer of activated B cells; JAK-STAT: Janus kinase/signal transducers and activators of transcription; Anx2: annexin A2; MEK2: mitogen-activated protein kinase kinase 2; eEF1A: eukaryotic elongation factor 1-alpha 1; HSP70: heat shock protein 70; GBP1: guanylate-binding protein 1; CD46: cluster of differentiation 46; Rab: Ras-related in brain; HO-1: heme oxygenase 1. 


\subsection{Viral Proteins Block the Host Innate Immunity}

Viruses have evolutionary evolved strategies to evade host innate immune responses for successful virus replication. To facilitate virus infection, CSFV N ${ }^{\text {pro }}$ interacts with IFN regulatory factor-3 (IRF-3) or IRF-7 and blocks type I IFN induction [76,77]. The structure of BVDV $\mathrm{N}^{\text {pro }}$ has been resolved, and the interaction domain harbors a TRASH motif to recognize the immune factors [88]. The host poly(C)-binding protein 1 (PCBP1) negatively regulates the type I IFN pathway and enhances CSFV growth [78]. Hemoglobin subunit beta (HB) interacts with the $C$ protein and antagonizes CSFV replication via the RIG-I-mediated IFN signaling, whereas CSFV inhibits expression of HB to block the pathway [81]. Our recent study has shown that thioredoxin 2 (Trx2) interacts with E2 and negatively regulates CSFV replication via nuclear factor kappa-light-chain-enhancer of activated B cells (NF- $\mathrm{kB}$ ) signaling, whereas CSFV inhibits protein expression of Trx2 to antagonize the antiviral effects [84]. Another study shows that mitogen-activated protein kinase kinase 2 (MEK2) interacts with the E2 protein and promotes CSFV replication via attenuation of the Janus kinase/signal transducers and activators of transcription (JAK-STAT) signaling pathway [85]. Recently, host guanylate-binding protein 1 (GBP1) has been shown to inhibit CSFV replication depending on its GTPase activity. As an antagonism, CSFV blocks the antiviral activities of GBP1 via inhibition of GBP1 expression [86]. Furthermore, the interaction between $\mathrm{N}^{\text {pro }}$ and $\mathrm{I} \kappa \mathrm{B} \alpha$ (the inhibitor of NF- $\mathrm{kB}$ ) may be involved in the modulation of the NF-kB signaling pathway [79] (Figure 4).

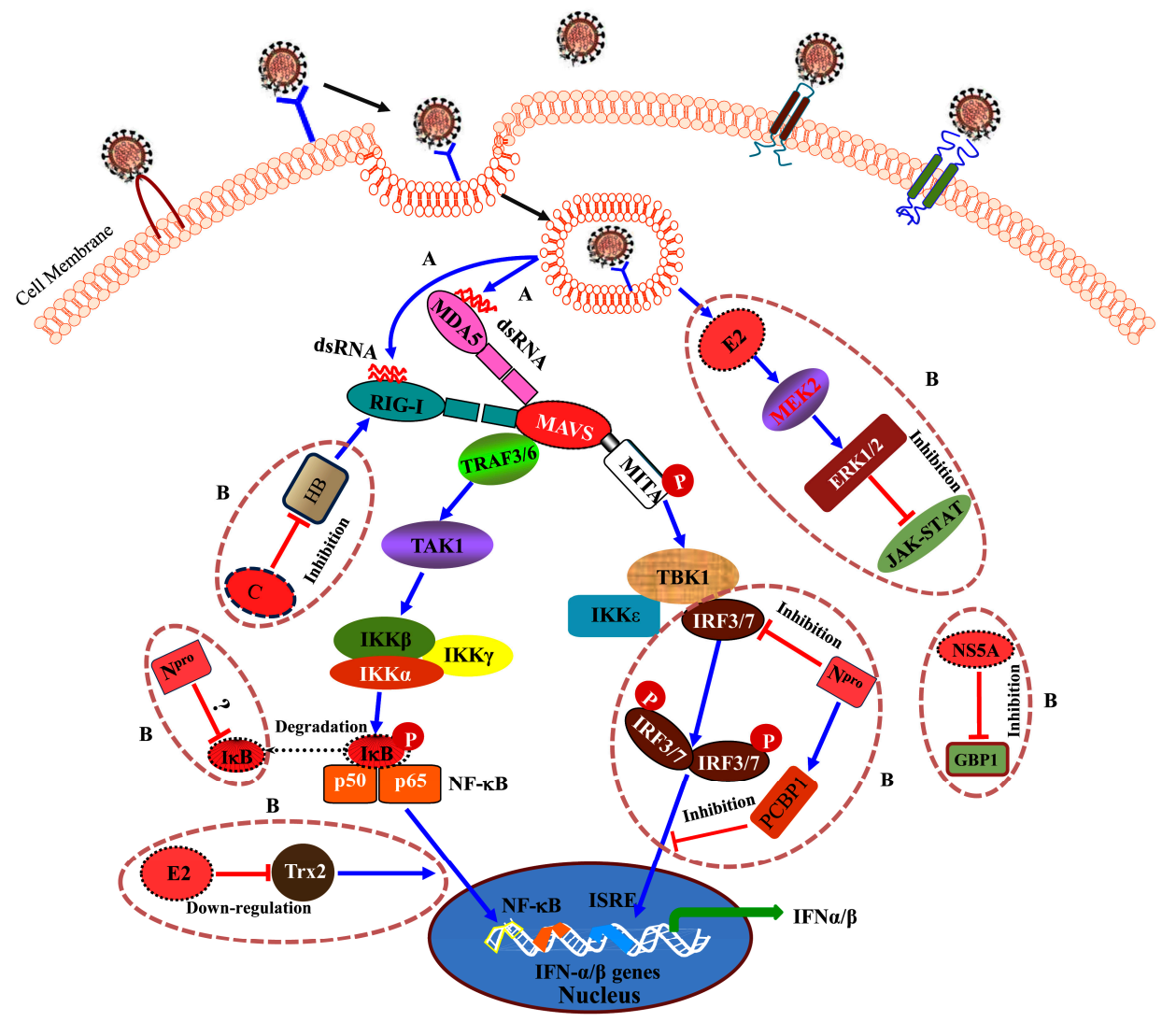

Figure 4. Activation and blockage of the intracellular signaling pathways of innate immunity during CSFV infection. (A) CSFV RNA is sensed by melanoma differentiation-associated protein 5 (MDA-5) and retinoic acid inducible gene I (RIG-I). (B) CSFV blocks the host innate immunity through multiple steps. 


\subsection{Disruption of Some Virus-Host Interactions Affects the Viral Virulence in Pigs}

SUMOylation is a post-translational modification involved in various cellular processes, such as transport, transcriptional regulation, protein stability, cell apoptosis, stress response, and progression of the cell cycle. Viruses have evolved various strategies to evade the host immune response through interacting the cellular SUMOylation pathway [89-91], thus destruction of the interaction between virus and host usually attenuates viral virulence [92]. It has been demonstrated that the $C$ protein of CSFV interacts with SUMO-1 (small ubiquitin-like modifier 1) and UBC9 (SUMO-1-conjugating enzyme 9) of the SUMOylation pathway [82]. Intriguingly, the virulence of mutant viruses, which are defective in binding to components of the SUMOylation pathway, is completely attenuated in pigs [82]. The cytoskeleton is required for the life cycle of flaviviruses [63]. As a major cytoskeleton regulator, Ras GTPase-activating-like protein 1 (IQGAP1) interacts with the $C$ protein, and a disruption of such interaction also results in the attenuation of viral virulence [83] (Table 1).

\section{Changes of Cell Apoptosis and Cell Cycle Induced by CSFV Infection}

Acute CSF is associated with high fever, leukopenia, thrombocytopenia, and hemorrhages observed in various organs. During the processes of acute CSF, the virus induces aberrant levels of type I IFN and pro-inflammatory mediators causing a so-called cytokine storm $[93,94]$. It has been shown that lymphocyte depletion is associated with the strong IFN- $\alpha$ response [94]. In addition, interleukin (IL)- $1 \alpha$, IL-6, and tumor necrosis factor (TNF)- $\alpha$ appeared to be the major cytokines involved in lymphocytopenia [95]. Another study has shown that CSFV infection induces the expression of apoptotic genes, such as CD49d, major histocompatibility complex (MHC) class II, and Fas [8]. Virus components can induce or inhibit apoptosis. Previous studies indicated that $E^{\text {rns }}, 5^{\prime}-$ or $3^{\prime}-\mathrm{NCR}$ of CSFV can induce lymphocyte apoptosis in vivo $[96,97]$. However, some of the viral proteins, such as $\mathrm{N}^{\text {pro }}$ and NS2, can inhibit cell apoptosis in vitro $[98,99]$. As a multi-functional protein, $\mathrm{N}^{\text {pro }}$ can antagonize the double-stranded RNA-mediated apoptosis [98], whereas, it cannot suppress the apoptosis induced by the NCRs of CSFV [97]. In addition, N ${ }^{\text {pro }}$ binds to HS-1-associated protein X 1 (HAX-1, an anti-apoptotic protein) and leads to a redistribution of HAX-1 from the mitochondria to the endoplasmic reticulum (ER), which might increase cellular resistance to apoptosis [80]. The NS2 protein can inhibit MG132-induced apoptosis, and the expression of NS2 results in the cell cycle arrest at S-phase and the induction of ER stress in the swine umbilical vein endothelial cells $[99,100]$. It is possible that the apoptosis induced by CSFV infection in vivo is associated with the magnitude of cytokine production.

\section{Concluding Remarks and Prospects}

The eventual outcome of viral infection usually relies on the host response to the virus. The virus life cycle consists of attachment, entry, uncoating, biosynthesis, assembly, and release. Attachment factors serve to bind the virion and thus help to concentrate viruses on the cell surface. These factors include HS and other carbohydrate structures on the cell surface. However, the factors usually cannot activate the downstream signals of the host to mediate virus entry. The entry receptor(s) can trigger conformational changes of the virion, activate host signaling pathways, and promote endocytic internalization. The attachment of CSFV is mediated by the host cellular HS or/and LamR $[15,16]$. As HS or LamR cannot mediate virus internalization, the virus maybe bind to an unknown entry receptor and trigger signaling pathways, such as clathrin-mediated endocytic pathway. CSFV can be internalized by clathrin-mediated endocytosis [58]. Entry of BVDV into Madin-Darby bovine kidney (MDBK) cells also requires active clathrin-dependent endocytosis [59]. However, viruses have evolved divergent strategies to invade host cells, e.g., the entry of influenza virus into simian kidney epithelial cells shows that almost $60 \%$ of the particles enter via clathrin-coated pits, whereas $40 \%$ use a clathrin-independent pathway [101]. Chlorpromazine, an inhibitor of clathrin lattice polymerization, cannot abrogate the CSFV infection [58], thus we presume that CSFV can be internalized via the 
clathrin-independent pathway. Furthermore, the low $\mathrm{pH}$ facilitates virus membrane fusion [17,58], indicating that the fusion step occurs in the endosome but not the cellular membrane. However, the entry receptors have not been defined, and the detailed entry and fusion mechanisms of CSFV remain to be revealed. Host factors also participate in viral genome replication and translation. Cytoplasmic RNA helicase A (RHA) participates in the modulation of RNA synthesis, replication, and translation of CSFV through binding $5^{\prime}$ - and $3^{\prime}$-NCRs [75]. Anx2 has been shown to interact with E2 and NS5A, enhancing viral growth and assembly [69,70]. Thus, we speculate that Anx2 plays critical roles in the multiple phases of the virus life cycle. Furthermore, host heme oxygenase 1 (HO-1) positively regulates CSFV replication [87]. In addition, eEF1A has been demonstrated to modulate viral genome translation through binding to the viral IRES [73]. During virus infection, the cytoskeletal proteins play an essential role in the viral transport and egress processes. The interaction between $\beta$-actin and E2 proteins affects the early stage of the replication [64], indicating that $\beta$-actin may participate in the transport process of the virus at the post-entry step of the virus life cycle. The process of virus assembly usually involves protein-protein interactions between viral structural proteins and NSPs and the coordinated action of host factors. HCV, DENV, and Japanese encephalitis virus are assembled at ER-derived membranes and exit the cell through the secretory pathway. Host factors, such as Anx2, endosomal sorting complexes required for sorting (ESCRT) components, and Rab18 promote virus assembly, ER budding, and maturation [102]. Anx2 has been shown to interact with NS5A to enhance CSFV assembly [70]. However, detailed dissection of CSFV assembly and release remains to be demonstrated. Taken together, future studies should be focused on the mechanisms of the virus entry, assembly, and release.

Virus infection can trigger a series of signaling cascades in host cells. To establish and maintain persistent infection, the CSFV Npro targets IRF3 and IRF7 to block type I IFN production [76,77], NS5A antagonizes the antiviral activity of GBP1 [86], and C inhibits the RIG-I-mediated IFN- $\beta$ signaling pathway through interacting with HB [81]. Thus, it seems that CSFV antagonizes the host innate immunity through multiple mechanisms. Novel insights into the mutual antagonism of the virus and host innate immunity will be beneficial for providing valuable targets for virus attenuation. It has been demonstrated that CSFV replicates poorly in cells from MxA-transgenic pigs [103]. More recently, it was reported that the monocytes and macrophages from the genome-edited pigs lacking the scavenger receptor cysteine-rich domain 5 (SRCR5) of CD163 are completely resistant to porcine reproductive and respiratory syndrome virus infection [104]. Dissection of the interplay between CSFV and the host will undoubtedly enrich the understanding of CSFV pathogenesis and facilitate the development of novel strategies for the control and eradication of CSF, such as development of novel antiviral agents, construction of quickly attenuated, efficacious, and highly productive vaccine strains, and generation of CSF-resistant transgenic pigs.

Acknowledgments: This work was supported by the Natural Science Foundation of China (grants 31630080, 31672537, and 31572540).

Author Contributions: All the authors reviewed the literature and wrote the manuscript.

Conflicts of Interest: The authors declare no conflict of interest.

\section{References}

1. Ji, W.; Guo, Z.; Ding, N.Z.; He, C.Q. Studying classical swine fever virus: Making the best of a bad virus. Virus Res. 2015, 197, 35-47. [CrossRef] [PubMed]

2. Tu, C.; Lu, Z.; Li, H.; Yu, X.; Liu, X.; Li, Y.; Zhang, H.; Yin, Z. Phylogenetic comparison of classical swine fever virus in China. Virus Res. 2001, 81, 29-37. [CrossRef]

3. Luo, Y.; Ji, S.; Liu, Y.; Lei, J.L.; Xia, S.L.; Wang, Y.; Du, M.L.; Shao, L.; Meng, X.Y.; Zhou, M.; et al. Isolation and characterization of a moderately virulent classical swine fever virus emerging in China. Transbound. Emerg. Dis. 2016. [CrossRef] [PubMed] 
4. Tu, C. Classical swine fever: International trend, Chinese status and control measures. Sci. Agri. Sin. 2003, 36, 955-960.

5. Zhu, Y.; Shi, Z.; Drew, T.W.; Wang, Q.; Qiu, H.; Guo, H.; Tu, C. Antigenic differentiation of classical swine fever viruses in China by monoclonal antibodies. Virus Res. 2009, 142, 169-174. [CrossRef] [PubMed]

6. Pletnev, A.; Gould, E.; Heinz, F.X.; Meyers, G.; Thiel, H.J.; Bukh, J.; Stiasny, K.; Collett, M.S.; Becher, P.; Simmonds, P.; et al. Flaviviridae. In Virus Taxonomy: Classification and Nomenclature of Viruses. Ninth Report of the International Committee on Taxonomy of Viruses; King, A.M.Q., Adams, M.J., Carstens, E.B., Lefkowitz, E.J., Eds.; Academic Press: London, UK, 2011; pp. 1003-1020.

7. Lindenbach, B.D.; Murray, C.L.; Thiel, H.J. Flaviviridae. In Fields Virology, 6th ed.; Knipe, D.M., Howley, P.M., Cohen, J.I., Griffin, D.E., Lamb, R.A., Martin, M.A., Racaniello, V.R., Roizman, B., Eds.; Lippincott Williams \& Wilkins: Philadelphia, PA, USA, 2013; Volume 2, pp. 712-746.

8. Summerfield, A.; Knötig, S.M.; McCullough, K.C. Lymphocyte apoptosis during classical swine fever: Implication of activation-induced cell death. J. Virol. 1998, 72, 1853-1861. [PubMed]

9. Summerfield, A.; Knötig, S.M.; Tschudin, R.; McCullough, K.C. Pathogenesis of granulocytopenia and bone marrow atrophy during classical swine fever involves apoptosis and necrosis of uninfected cells. Virology 2000, 272, 50-60. [CrossRef] [PubMed]

10. Branza-Nichita, N.; Lazar, C.; Dwek, R.A.; Zitzmann, N. Role of N-glycan trimming in the folding and secretion of the pestivirus protein $E^{\text {rns }}$. Biochem. Biophys. Res. Commun. 2004, 319, 655-662. [CrossRef] [PubMed]

11. Thiel, H.J.; Stark, R.; Weiland, E.; Rümenapf, T.; Meyers, G. Hog cholera virus: Molecular composition of virions from a pestivirus. J. Virol. 1991, 65, 4705-4712. [PubMed]

12. Lazar, C.; Zitzmann, N.; Dwek, R.A.; Branza-Nichita, N. The pestivirus $E^{\text {rns }}$ glycoprotein interacts with E2 in both infected cells and mature virions. Virology 2003, 2, 696-705. [CrossRef]

13. Krey, T.; Bontems, F.; Vonrhein, C.; Vaney, M.C.; Bricogne, G.; Rümenapf, T.; Rey, F.A. Crystal structure of the pestivirus envelope glycoprotein $\mathrm{E}^{\mathrm{rns}}$ and mechanistic analysis of its ribonuclease activity. Structure 2012, 20, 862-873. [CrossRef] [PubMed]

14. Aberle, D.; Muhle-Goll, C.; Bürck, J.; Wolf, M.; Reißer, S.; Luy, B.; Wenzel, W.; Ulrich, A.S.; Meyers, G. Structure of the membrane anchor of pestivirus glycoprotein $\mathrm{E}^{\mathrm{rns}}$, a long tilted amphipathic helix. PLoS Pathog. 2014, 10, e1003973. [CrossRef] [PubMed]

15. Hulst, M.M.; van Gennip, H.G.; Moormann, R.J. Passage of classical swine fever virus in cultured swine kidney cells selects virus variants that bind to heparan sulfate due to a single amino acid change in envelope protein $\mathrm{E}^{\mathrm{rns}}$. J. Virol. 2000, 74, 9553-9561. [CrossRef] [PubMed]

16. Chen, J.; He, W.R.; Shen, L.; Dong, H.; Yu, J.; Wang, X.; Yu, S.; Li, Y.; Li, S.; Luo, Y.; et al. The laminin receptor is a cellular attachment receptor for classical swine fever virus. J. Virol. 2015, 89, 4894-4906. [CrossRef] [PubMed]

17. Wang, Z.; Nie, Y.; Wang, P.; Ding, M.; Deng, H. Characterization of classical swine fever virus entry by using pseudotyped viruses: E1 and E2 are sufficient to mediate viral entry. Virology 2004, 330, 332-341. [CrossRef] [PubMed]

18. El Omari, K.; Iourin, O.; Harlos, K.; Grimes, J.M.; Stuart, D.I. Structure of a pestivirus envelope glycoprotein E2 clarifies its role in cell entry. Cell Rep. 2013, 3, 30-35. [CrossRef] [PubMed]

19. König, M.; Lengsfeld, T.; Pauly, T.; Stark, R.; Thiel, H.J. Classical swine fever virus: Independent induction of protective immunity by two structural glycoproteins. J. Virol. 1995, 69, 6479-6486. [PubMed]

20. Yu, X.; Tu, C.; Li, H.; Hu, R.; Chen, C.; Li, Z.; Zhang, M.; Yin, Z. DNA-mediated protection against classical swine fever virus. Vaccine 2001, 19, 1520-1525. [CrossRef]

21. Li, N.; Qiu, H.J.; Zhao, J.J.; Li, Y.; Wang, M.J.; Lu, B.W.; Han, C.G.; Hou, Q.; Wang, Z.H.; Gao, H.; et al. A Semliki forest virus replicon vectored DNA vaccine expressing the E2 glycoprotein of classical swine fever virus protects pigs from lethal challenge. Vaccine 2007, 25, 2907-2912. [CrossRef] [PubMed]

22. Sun, Y.; Li, H.Y.; Tian, D.Y.; Han, Q.Y.; Zhang, X.; Li, N.; Qiu, H.J. A novel alphavirus replicon-vectored vaccine delivered by adenovirus induces sterile immunity against classical swine fever. Vaccine 2011, 29, 8364-8372. [CrossRef] [PubMed]

23. Gavrilov, B.K.; Rogers, K.; Fernández-Sainz, I.J.; Holinka, L.G.; Borca, M.V.; Risatti, G.R. Effects of glycosylation on antigenicity and immunogenicity of classical swine fever virus envelope proteins. Virology 2011, 420, 135-145. [CrossRef] [PubMed] 
24. Wensvoort, G. Topographical and functional mapping of epitopes on hog cholera virus with monoclonal antibodies. J. Gen. Virol. 1989, 70, 2865-2876. [CrossRef] [PubMed]

25. Lin, M.; Lin, F.; Mallory, M.; Clavijo, A. Deletions of structural glycoprotein E2 of classical swine fever virus strain Alfort/187 resolve a linear epitope of monoclonal antibody WH303 and the minimal N-terminal domain essential for binding immunoglobulin G antibodies of a pig hyperimmune serum. J. Virol. 2000, 24, 11619-11625. [CrossRef]

26. Liu, S.; Yu, X.; Wang, C.; Wu, J.; Kong, X.; Tu, C. Quadruple antigenic epitope peptide producing immune protection against classical swine fever virus. Vaccine 2006, 24, 7175-7180. [CrossRef] [PubMed]

27. Qi, Y.; Zhang, B.Q.; Shen, Z.; Chen, Y.H. Antigens containing TAVSPTTLR tandem repeats could be used in assaying antibodies to classical swine fever virus. Acta Virol. 2009, 53, 241-246. [CrossRef] [PubMed]

28. Li, G.X.; Zhou, Y.J.; Yu, H.; Li, L.; Wang, Y.X.; Tong, W.; Hou, J.W.; Xu, Y.Z.; Zhu, J.P.; Xu, A.T.; et al. A novel dendrimeric peptide induces high level neutralizing antibodies against classical swine fever virus in rabbits. Vet. Microbiol. 2012, 156, 200-204. [CrossRef] [PubMed]

29. Van der Wal, F.J.; Jelsma, T.; Fijten, H.; Achterberg, R.P.; Loeffen, W.L. Towards a peptide-based suspension array for the detection of pestivirus antibodies in swine. J. Virol. Methods 2016, 235, 15-20. [CrossRef] [PubMed]

30. Li, Y.; Wang, J.; Kanai, R.; Modis, Y. Crystal structure of glycoprotein E2 from bovine viral diarrhea virus. Proc. Natl. Acad. Sci. USA 2013, 110, 6805-6810. [CrossRef] [PubMed]

31. Fernández-Sainz, I.J.; Largo, E.; Gladue, D.P.; Fletcher, P.; O’Donnell, V.; Holinka, L.G.; Carey, L.B.; Lu, X.; Nieva, J.L.; Borca, M.V. Effect of specific amino acid substitutions in the putative fusion peptide of structural glycoprotein E2 on classical swine fever virus replication. Virology 2014, 456-457, 121-130. [CrossRef] [PubMed]

32. Holinka, L.G.; Largo, E.; Gladue, D.P.; O’Donnell, V.; Risatti, G.R.; Nieva, J.L.; Borca, M.V. Alteration of a second putative fusion peptide of structural glycoprotein E2 of classical swine fever virus alters virus replication and virulence in swine. J. Virol. 2016, 90, 10299-10308. [CrossRef] [PubMed]

33. Maurer, K.; Krey, T.; Moennig, V.; Thiel, H.J.; Rümenapf, T. CD46 is a cellular receptor for bovine viral diarrhea virus. J. Virol. 2004, 78, 1792-1799. [CrossRef] [PubMed]

34. Dräger, C.; Beer, M.; Blome, S. Porcine complement regulatory protein CD46 and heparan sulfates are the major factors for classical swine fever virus attachment in vitro. Arch. Virol. 2015, 160, 739-746. [CrossRef] [PubMed]

35. Björklund, H.; Stadejek, T.; Belák, S. Molecular characterization of the $3^{\prime}$ non-coding region of classical swine fever virus vaccine strains. Virus Genes 1998, 16, 307-312. [CrossRef] [PubMed]

36. Risager, P.C.; Fahnøe, U.; Gullberg, M.; Rasmussen, T.B.; Belsham, G.J. Analysis of classical swine fever virus RNA replication determinants using replicons. J. Gen. Virol. 2013, 94, 1739-1748. [CrossRef] [PubMed]

37. Lackner, T.; Thiel, H.J.; Tautz, N. Dissection of a viral autoprotease elucidates a function of a cellular chaperone in proteolysis. Proc. Natl. Acad. Sci. USA 2006, 103, 1510-1515. [CrossRef] [PubMed]

38. Moulin, H.R.; Seuberlich, T.; Bauhofer, O.; Bennett, L.C.; Tratschin, J.D.; Hofmann, M.A.; Ruggli, N. Nonstructural proteins NS2-3 and NS4A of classical swine fever virus: Essential features for infectious particle formation. Virology 2007, 365, 376-389. [CrossRef] [PubMed]

39. Agapov, E.V.; Murray, C.L.; Frolov, I.; Qu, L.; Myers, T.M.; Rice, C.M. Uncleaved NS2-3 is required for production of infectious bovine viral diarrhea virus. J. Virol. 2004, 78, 2414-2425. [CrossRef] [PubMed]

40. Klemens, O.; Dubrau, D.; Tautz, N. Characterization of the determinants of NS2-3-independent virion morphogenesis of Pestiviruses. J. Virol. 2015, 89, 11668-11680. [CrossRef] [PubMed]

41. Tamura, J.K.; Warrener, P.; Collett, M.S. RNA-stimulated NTPase activity associated with the p80 protein of the pestivirus bovine viral diarrhea virus. Virology 1993, 193, 1-10. [CrossRef] [PubMed]

42. Warrener, P.; Collett, M.S. Pestivirus NS3 (p80) protein possesses RNA helicase activity. J. Virol. 1995, 69, 1720-1726. [PubMed]

43. Wiskerchen, M.; Collett, M.S. Pestivirus gene expression: Protein p80 of bovine viral diarrhea virus is a proteinase involved in polyprotein processing. Virology 1991, 184, 341-350. [CrossRef]

44. Tautz, N.; Kaiser, A.; Thiel, H.J. NS3 serine protease of bovine viral diarrhea virus: Characterization of active site residues, NS4A cofactor domain, and protease-cofactor interactions. Virology 2000, 273, 351-363. [CrossRef] [PubMed] 
45. Dubrau, D.; Tortorici, M.A.; Rey, F.A.; Tautz, N. A positive-strand RNA virus uses alternative protein-protein interactions within a viral protease/cofactor complex to switch between RNA replication and virion morphogenesis. PLoS Pathog. 2017, 13, e1006134. [CrossRef] [PubMed]

46. Gladue, D.; Gavrilov, B.K.; Holinka, L.G.; Fernández-Sainz, I.J.; Vepkhvadze, N.; Rogers, K.; O’Donnell, V.; Risatti, G.R.; Borca, M.V. Identification of an NTPase motif in classical swine fever virus NS4B protein. Virology 2011, 411, 41-49. [CrossRef] [PubMed]

47. Fernandez-Sáinz, I.; Gladue, D.P.; Holinka, L.G.; O’Donnell, V.; Gudmundsdottir, I.; Prarat, M.V.; Patch, J.R.; Golde, W.T.; Lu, Z.; Zhu, J.; et al. Mutations in classical swine fever virus NS4B affect virulence in swine. J. Virol. 2010, 3, 1536-1539. [CrossRef] [PubMed]

48. Reed, K.E.; Gorbalenya, A.E.; Rice, C.M. The NS5A/NS5 proteins of viruses from three genera of the family Flaviviridae are phosphorylated by associated serine/threonine kinases. J. Virol. 1998, 72, 6199-6206. [PubMed]

49. Pei, J.; Zhao, M.; Ye, Z.; Gou, H.; Wang, J.; Yi, L.; Dong, X.; Liu, W.; Luo, Y.; Liao, M.; et al. Autophagy enhances the replication of classical swine fever virus in vitro. Autophagy 2013, 10, 93-110. [CrossRef] [PubMed]

50. Pei, J.; Deng, J.; Ye, Z.; Wang, J.; Gou, H.; Liu, W.; Zhao, M.; Liao, M.; Yi, L.; Chen, J. Absence of autophagy promotes apoptosis by modulating the ROS-dependent RLR signaling pathway in classical swine fever virus-infected cells. Autophagy 2016, 12, 1738-1758. [CrossRef] [PubMed]

51. Wang, Y.; Xiao, M.; Chen, J.; Zhang, W.; Luo, J.; Bao, K.; Nie, M.; Chen, J.; Li, B. Mutational analysis of the GDD sequence motif of classical swine fever virus RNA-dependent RNA polymerases. Virus Genes 2007, 34, 63-65. [CrossRef]

52. Choi, K.H.; Gallei, A.; Becher, P.; Rossmann, M.G. The structure of bovine viral diarrhea virus RNA-dependent RNA polymerase and its amino-terminal domain. Structure 2006, 14, 1107-1113. [CrossRef] [PubMed]

53. Xiao, M.; Gao, J.; Wang, W.; Wang, Y.; Chen, J.; Chen, J.; Li, B. Specific interaction between the classical swine fever virus NS5B protein and the viral genome. Eur. J. Biochem. 2004, 271, 3888-3896. [CrossRef] [PubMed]

54. Xiao, M.; Bai, Y.; Xu, H.; Geng, X.; Chen, J.; Wang, Y.; Chen, J.; Li, B. Effect of NS3 and NS5B proteins on classical swine fever virus internal ribosome entry site-mediated translation and its host cellular translation. J. Gen. Virol. 2008, 89, 994-999. [CrossRef] [PubMed]

55. Sheng, C.; Chen, Y.; Xiao, J.; Xiao, J.; Wang, J.; Li, G.; Chen, J.; Xiao, M. Classical swine fever virus NS5A protein interacts with $3^{\prime}$-untranslated region and regulates viral RNA synthesis. Virus Res. 2012, 3, 636-643. [CrossRef] [PubMed]

56. Chen, Y.; Xiao, J.; Xiao, J.; Sheng, C.; Wang, J.; Jia, L.; Zhi, Y.; Li, G.; Chen, J.; Xiao, M. Classical swine fever virus NS5A regulates viral RNA replication through binding to NS5B and 3'-UTR. Virology 2012, 432, 376-388. [CrossRef] [PubMed]

57. Rijnbrand, R.; van der Straaten, T.; van Rijn, P.A.; Spaan, W.J.; Bredenbeek, P.J. Internal entry of ribosomes is directed by the $5^{\prime}$ noncoding region of classical swine fever virus and is dependent on the presence of an RNA pseudoknot upstream of the initiation codon. J. Virol. 1997, 71, 451-457. [PubMed]

58. Shi, B.J.; Liu, C.C.; Zhou, J.; Wang, S.Q.; Gao, Z.C.; Zhang, X.M.; Zhou, B.; Chen, P.Y. Entry of classical swine fever virus into PK-15 cells via a pH-, dynamin-, and cholesterol-dependent, clathrin-mediated endocytic pathway that requires Rab5 and Rab7. J. Virol. 2016, 90, 9194-9208. [CrossRef] [PubMed]

59. Lecot, S.; Belouzard, S.; Dubuisson, J.; Rouillé, Y. Bovine viral diarrhea virus entry is dependent on clathrin-mediated endocytosis. J. Virol. 2005, 79, 10826-10829. [CrossRef] [PubMed]

60. Manna, D.; Aligo, J.; Xu, C.; Park, W.S.; Koc, H.; Heo, W.D.; Konan, K.V. Endocytic Rab proteins are required for hepatitis C virus replication complex formation. Virology 2010, 398, 21-37. [CrossRef] [PubMed]

61. Van der Schaar, H.M.; Rust, M.J.; Chen, C.; van der Ende-Metselaar, H.; Wilschut, J.; Zhuang, X.; Smit, J.M. Dissecting the cell entry pathway of dengue virus by single-particle tracking in living cells. PLoS Pathog. 2008, 12, e1000244. [CrossRef] [PubMed]

62. Krishnan, M.N.; Sukumaran, B.; Pal, U.; Agaisse, H.; Murray, J.L.; Hodge, T.W.; Fikrig, E. Rab 5 is required for the cellular entry of dengue and West Nile viruses. J. Virol. 2007, 81, 4881-4885. [CrossRef] [PubMed]

63. Foo, K.Y.; Chee, H.Y. Interaction between Flavivirus and cytoskeleton during virus replication. Biomed. Res. Int. 2015, 2015, 427814. [CrossRef] [PubMed] 
64. He, F.; Ling, L.; Liao, Y.; Li, S.; Han, W.; Zhao, B.; Sun, Y.; Qiu, H.J. Beta-actin interacts with the E2 protein and is involved in the early replication of classical swine fever virus. Virus Res. 2014, 179, 161-168. [CrossRef] [PubMed]

65. Wright, J.F.; Kurosky, A.; Pryzdial, E.L.; Wasi, S. Host cellular annexin II is associated with cytomegalovirus particles isolated from cultured human fibroblasts. J. Virol. 1995, 69, 4784-4791. [PubMed]

66. Ryzhova, E.V.; Vos, R.M.; Albright, A.V.; Harrist, A.V.; Harvey, T.; González-Scarano, F. Annexin 2: A novel human immunodeficiency virus type $1 \mathrm{Gag}$ binding protein involved in replication in monocyte-derived macrophages. J. Virol. 2006, 80, 2694-2704. [CrossRef] [PubMed]

67. LeBouder, F.; Morello, E.; Rimmelzwaan, G.F.; Bosse, F.; Péchoux, C.; Delmas, B.; Riteau, B. Annexin II incorporated into influenza virus particles supports virus replication by converting plasminogen into plasmin. J. Virol. 2008, 82, 6820-6828. [CrossRef] [PubMed]

68. Backes, P.; Quinkert, D.; Reiss, S.; Binder, M.; Zayas, M.; Rescher, U.; Gerke, V.; Bartenschlager, R.; Lohmann, V. Role of annexin A2 in the production of infectious hepatitis C virus particles. J. Virol. 2010, 84, 5775-5789. [CrossRef] [PubMed]

69. Yang, Z.; Shi, Z.; Guo, H.; Qu, H.; Zhang, Y.; Tu, C. Annexin 2 is a host protein binding to classical swine fever virus E2 glycoprotein and promoting viral growth in PK-15 cells. Virus Res. 2015, 201, 16-23. [CrossRef] [PubMed]

70. Sheng, C.; Liu, X.; Jiang, Q.; Xu, B.; Zhou, C.; Wang, Y.; Chen, J.; Xiao, M. Annexin A2 is involved in the production of classical swine fever virus infectious particles. J. Gen. Virol. 2015, 96, 1027-1032. [CrossRef] [PubMed]

71. Gladue, D.; O’Donnell, V.; Fernández-Sainz, I.J.; Fletcher, P.; Baker-Branstetter, R.; Holinka, L.; Sanford, B.; Carlson, J.; Lu, Z.; Borca, M.V. Interaction of structural core protein of classical swine fever virus with endoplasmic reticulum-associated degradation pathway protein OS9. Virology 2014, 460, 173-179. [CrossRef] [PubMed]

72. Zhang, C.; Kang, K.; Ning, P.; Peng, Y.; Lin, Z.; Cui, H.; Cao, Z.; Wang, J.; Zhang, Y. Heat shock protein 70 is associated with CSFV NS5A protein and enhances viral RNA replication. Virology 2015, 482, 9-18. [CrossRef] [PubMed]

73. Li, S.; Feng, S.; Wang, J.H.; He, W.R.; Qin, H.Y.; Dong, H.; Li, L.F.; Yu, S.X.; Li, Y.; Qiu, H.J. eEF1A interacts with the NS5A protein and inhibits the growth of classical swine fever virus. Viruses 2015, 7, 4563-4581. [CrossRef] [PubMed]

74. Johnson, C.M.; Perez, D.R.; French, R.; Merrick, W.C.; Donis, R.O. The NS5A protein of bovine viral diarrhoea virus interacts with the alpha subunit of translation elongation factor-1. J. Gen. Virol. 2001, 82, 2935-2943. [CrossRef] [PubMed]

75. Sheng, C.; Yao, Y.; Chen, B.; Wang, Y.; Chen, J.; Xiao, M. RNA helicase is involved in the expression and replication of classical swine fever virus and interacts with untranslated region. Virus Res. 2013, 171, 257-261. [CrossRef] [PubMed]

76. Bauhofer, O.; Summerfield, A.; Sakoda, Y.; Tratschin, J.D.; Hofmann, M.A.; Ruggli, N. Classical swine fever

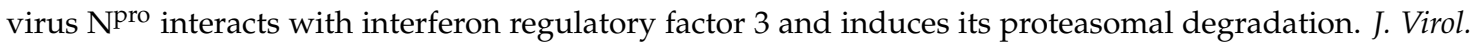
2007, 81, 3087-3096. [CrossRef] [PubMed]

77. Fiebach, A.R.; Guzylack-Piriou, L.; Python, S.; Summerfield, A.; Ruggli, N. Classical swine fever virus Npro limits type I interferon induction in plasmacytoid dendritic cells by interacting with interferon regulatory factor 7. J. Virol. 2011, 85, 8002-8011. [CrossRef] [PubMed]

78. Li, D.; Li, S.; Sun, Y.; Dong, H.; Li, Y.; Zhao, B.; Guo, D.; Weng, C.; Qiu, H.J. Poly(C)-binding protein 1, a novel $\mathrm{N}^{\mathrm{pro}}$-interacting protein involved in classical swine fever virus growth. J. Virol. 2013, 87, 2072-2080. [CrossRef] [PubMed]

79. Doceul, V.; Charleston, B.; Crooke, H.; Reid, E.; Powell, P.P.; Seago, J. The N ${ }^{\text {pro }}$ product of classical swine fever virus interacts with Ikappa B alpha, the NF-kappaB inhibitor. J. Gen. Virol. 2008, 89, 1881-1889. [CrossRef] [PubMed]

80. Johns, H.L.; Doceul, V.; Everett, H.; Crooke, H.; Charleston, B.; Seago, J. The classical swine fever virus N-terminal protease Npro binds to cellular HAX-1. J. Gen. Virol. 2010, 91, 2677-2686. [CrossRef] [PubMed]

81. Li, D.; Dong, H.; Li, S.; Munir, M.; Chen, J.; Luo, Y.; Sun, Y.; Liu, L.; Qiu, H.J. Hemoglobin subunit beta interacts with the capsid protein and antagonizes the growth of classical swine fever virus. J. Virol. 2013, 87, 5707-5717. [CrossRef] [PubMed] 
82. Gladue, D.; Holinka, L.; Fernández-Sainz, I.J.; Prarat, M.; O’Donell, V.; Vepkhvadze, N.; Lu, Z.; Rogers, K.; Risatti, G.; Borca, M.V. Effects of the interactions of classical swine fever virus Core protein with proteins of the SUMOylation pathway on virulence in swine. Virology 2010, 407, 129-136. [CrossRef] [PubMed]

83. Gladue, D.; Holinka, L.; Fernández-Sainz, I.J.; Prarat, M.; O’Donnell, V.; Vepkhvadze, N.; Lu, Z.; Risatti, G.; Borca, M.V. Interaction between Core protein of classical swine fever virus with cellular IQGAP1 protein appears essential for virulence in swine. Virology 2011, 412, 68-74. [CrossRef] [PubMed]

84. Li, S.; Wang, J.; He, W.R.; Feng, S.; Li, Y.; Wang, X.; Liao, Y.; Qin, H.Y.; Li, L.F.; Dong, H.; et al. Thioredoxin 2 is a novel E2-interacting protein that inhibits the replication of classical swine fever virus. J. Virol. 2015, 89, 8510-8524. [CrossRef] [PubMed]

85. Wang, J.; Chen, S.; Liao, Y.; Zhang, E.; Feng, S.; Yu, S.; Li, L.F.; He, W.R.; Li, Y.; Luo, Y.; et al. Mitogen-activated protein kinase kinase 2, a novel E2-interacting protein, promotes the growth of classical swine fever virus via attenuation of the JAK-STAT signaling pathway. J. Virol. 2016, 90, 10271-10283. [CrossRef] [PubMed]

86. Li, L.F.; Yu, J.H.; Li, Y.; Wang, J.; Li, S.; Zhang, L.K.; Xia, S.L.; Yang, Q.; Wang, X.; Yu, S.; et al. Guanylate-binding protein 1, an interferon-induced GTPase, exerts an antiviral activity against classical swine fever virus depending on its GTPase activity. J. Virol. 2016, 90, 4412-4426. [CrossRef] [PubMed]

87. Shi, Z.; Sun, J.; Guo, H.; Yang, Z.; Ma, Z.; Tu, C. Down-regulation of cellular protein heme oxygenase 1 inhibits proliferation of classical swine fever virus in PK-15 cells. Virus Res. 2013, 173, 315-320. [CrossRef] [PubMed]

88. Zögg, T.; Sponring, M.; Schindler, S.; Koll, M.; Schneider, R.; Brandstetter, H.; Auer, B. Crystal structures of the viral protease $\mathrm{N}^{\text {pro }}$ imply distinct roles for the catalytic water in catalysis. Structure 2013, 21, 929-938. [CrossRef] [PubMed]

89. Xu, K.; Klenk, C.; Liu, B.; Keiner, B.; Cheng, J.K.; Zheng, B.J.; Li, L.; Han, Q.L.; Wang, C.; Li, T.X.; et al. Modification of nonstructural protein 1 of influenza A virus by SUMO1. J. Virol. 2011, 85, 1086-1098. [CrossRef] [PubMed]

90. Han, Q.; Chang, C.; Li, L.; Klenk, C.; Cheng, J.; Chen, Y.; Xia, N.; Shu, Y.; Chen, Z.; Gabriel, G.; et al. SUMOylation of influenza A virus nucleoprotein is essential for intracellular trafficking and virus growth. J. Virol. 2014, 88, 9379-9390. [CrossRef] [PubMed]

91. Higginbotham, J.M.; O'Shea, C.C. Adenovirus E4-ORF3 targets PIAS3 and together with E1B-55K remodels SUMO interactions in the nucleus and at virus genome replication domains. J. Virol. 2015, 89, 10260-10272. [CrossRef] [PubMed]

92. Richt, J.A.; García-Sastre, A. Attenuated influenza virus vaccines with modified NS1 proteins. Curr. Top. Microbiol. Immunol. 2009, 333, 177-195. [PubMed]

93. Sanchez-Cordon, P.J.; Romanini, S.; Salguero, F.J.; Nunez, A.; Bautista, M.J.; Jover, A.; Gomez-Villamos, J.C. Apoptosis of thymocytes related to cytokine expression in experimental classical swine fever. J. Comp. Pathol. 2002, 127, 239-248. [CrossRef] [PubMed]

94. Summerfield, A.; Alves, M.; Ruggli, N.; de Bruin, M.G.; McCullough, K.C. High IFN-alpha responses associated with depletion of lymphocytes and natural IFN-producing cells during classical swine fever. J. Interferon Cytokine Res. 2006, 26, 248-255. [CrossRef] [PubMed]

95. Sánchez-Cordón, P.J.; Núñez, A.; Salguero, F.J.; Pedrera, M.; Fernández de Marco, M.; Gómez-Villamandos, J.C. Lymphocyte apoptosis and thrombocytopenia in spleen during classical swine fever: Role of macrophages and cytokines. Vet. Pathol. 2005, 42, 477-488. [CrossRef] [PubMed]

96. Bruschke, C.J.; Hulst, M.M.; Moormann, R.J.; van Rijn, P.A.; van Oirschot, J.T. Glycoprotein $\mathrm{E}^{\mathrm{rns}}$ of pestiviruses induces apoptosis in lymphocytes of several species. J. Virol. 1997, 71, 6692-6696. [PubMed]

97. Hsu, W.L.; Chen, C.L.; Huang, S.W.; Wu, C.C.; Chen, I.H.; Nadar, M.; Su, Y.P.; Tsai, C.H. The untranslated regions of classic swine fever virus RNA trigger apoptosis. PLoS ONE 2014, 9, e88863. [CrossRef] [PubMed]

98. Ruggli, N.; Bird, B.H.; Liu, L.; Bauhofer, O.; Tratschin, J.D.; Hofmann, M.A. N ${ }^{\text {pro }}$ of classical swine fever virus is an antagonist of double-stranded RNA-mediated apoptosis and IFN- $\alpha$ / $\beta$ induction. Virology 2005, 340, 265-276. [CrossRef] [PubMed]

99. Tang, Q.H.; Guo, K.; Kang, K.; Zhang, Y.; He, L.; Wang, J. Classical swine fever virus NS2 protein promotes interleukin-8 expression and inhibits MG132-induced apoptosis. Virus Genes 2011, 42, 355-362. [CrossRef] [PubMed] 
100. Tang, Q.H.; Zhang, Y.M.; Fan, L.; Tong, G.; He, L.; Dai, C. Classic swine fever virus NS2 protein leads to the induction of cell cycle arrest at S-phase and endoplasmic reticulum stress. Virol. J. 2010, 7, 4. [CrossRef] [PubMed]

101. Rust, M.J.; Lakadamyali, M.; Zhang, F.; Zhuang, X. Assembly of endocytic machinery around individual influenza viruses during viral entry. Nat. Struct. Mol. Biol. 2004, 11, 567-573. [CrossRef] [PubMed]

102. Gerold, G.; Bruening, J.; Weigel, B.; Pietschmann, T. Protein interactions during the Flavivirus and Hepacivirus life cycle. Mol. Cell. Proteom. 2017, 16, 75-91. [CrossRef] [PubMed]

103. Zhao, Y.; Wang, T.; Yao, L.; Liu, B.; Teng, C.; Ouyang, H.S. Classical swine fever virus replicated poorly in cells from MxA transgenic pigs. BMC Vet. Res. 2016, 12, 169. [CrossRef] [PubMed]

104. Burkard, C.; Lillico, S.G.; Reid, E.; Jackson, B.; Mileham, A.J.; Ait-Ali, T.; Whitelaw, C.B.; Archibald, A.L. Precision engineering for PRRSV resistance in pigs: Macrophages from genome edited pigs lacking CD163 SRCR5 domain are fully resistant to both PRRSV genotypes while maintaining biological function. PLoS Pathog. 2017, 13, e1006206. [CrossRef] [PubMed]

(C) 2017 by the authors. Licensee MDPI, Basel, Switzerland. This article is an open access article distributed under the terms and conditions of the Creative Commons Attribution (CC BY) license (http:// creativecommons.org/licenses/by/4.0/). 